\title{
PENGARUH HEAD LINE DAN KOMENTAR NETIZEN TERHADAP MINAT MEMBACA BERITA PADA DETIK.COM
}

\author{
Edy Prihantoro, Musti Ana, Emilianshah Banowo \\ Universitas Gunadarma-AKMRTV Jakarta \\ edipri@staff.gunadarma.ac.id, mustianamusti@gmail.com, emil@akmrtv.ac.id
}

\begin{abstract}
ABSTRAK
Head line dan komentar memiliki daya tarik bagi pembaca media massa online. Headline yang menarik serta komentar para netizen dapat mempengaruhi pembaca untuk tertarik membaca berita-berita pada media massa online. Penelitian ini menggunakan metode kuantitatif dengan pendekatan eksplanatif dengan menggunakan metode survey untuk memperoleh data. Teknik analasis data pada penelitian ini menggunakan analisis regresi linier berganda. Dengan jumlah populasi yang tidak diketahui jumlahnya, sehingga sampel yang diperoleh berdasarkan perhitungan dengan tingkat kesalahan 1\% menjadi 96 orang dengan rumus Lemeshow. Pada penelitian ini menggunakan teori uses and gratification karena teori ini menjelaskan bahwa pengguna media memiliki kebutuhan tertentu yang mendorong terjadinya penggunaan media (uses) untuk memperoleh kepuasan (gratification). Juga menggunakan teori S-O-R yang menjelaskan stimulus atau pesan yang disampaikan kepada komunikan mungkin diterima atau mungkin ditolak. Komunikasi akan berlangsung jika ada perhatian dari komunikan. Hasil penelitian menunjukkan bahwa antara variabel headline dan komentar netizen, keduanya memberikan pengaruh yang signifikan terhadap minat membaca berita di media online detik.com. Ketertarikan terhadap headline dan komentar pada detik.com ternyata menjadi daya tarik yang besar bagi pembaca untuk membaca dan melihat lebih dalam sebuah berita yang disajikan detik.com
\end{abstract}

Kata Kunci : headline, komentar, berita, minat baca 


\section{Acta Diurna Vol 15 No 1 Tahun 2019}

\section{PENDAHULUAN}

Penggunaan media online saat ini semakin meningkat, dikarenakan informasi yang lebih cepat didapatkan. Selain itu media online jauh lebih efisien, hanya dengan menggunakan koneksi internet maka masyarakat dapat mengakses berita dari media online tersebut. Hal ini jauh lebih efisien daripada harus membeli surat kabar setiap harinya. Faktor lain yang tak kalah penting dalam pembuatan portal berita media online adalah kepraktisan dalam mendapatkan informasi yang update tiap saat.

Karena kelebihan tersebut, saat ini ada banyak sekali media online di Indonesia yang menyajikan berita-berita. Salah satunya adalah detik.com, sebuah portal berita yang berisi berita aktual dan artikel di Indonesia. Detik.com merupakan salah satu situs berita terpopuler di Indonesia. Berbeda dari situs-situs berita berbahasa Indonesia lainnya, detik.com hanya mempunyai edisi online dan menggantungkan pendapatan dari bidang iklan. Meskipun begitu, detik.com merupakan yang terdepan dalam hal berita-berita baru (breaking news).

Detik.com mendapatkan iklan berdasarkan Traffic. Traffic adalah aktivitas pada satu halaman situs yang dihasilkan dari kunjungan pengguna internet dan aktivitas dari netizen (warga internet) di halaman itu. Semakin banyak sebuah situs dikunjungi dan semakin banyak aktivitas yang dilakukan oleh netizen di laman-laman situs itu, maka traffic situs itu semakin tinggi dan merupakan keuntungan media tersebut secara bisnis. Sehingga traffic itulah yang ditawarkan kepada pengiklan untuk memasang iklan.

Karena traffic adalah acuan utama untuk mendapatkan penghasilan dari sebuah media online, sehingga pembuatan headline harus menarik. Kolom komentar ditambahkan untuk memberikan fasilitas komentar bagi netizen untuk ikut berpendapat terkait berita. Headline dan komentar netizen pada kolom komentar sebagai objek 


\section{Acta Diurna Vol 15 No 1 Tahun 2019}

penelitian untuk mengetahui seberapa besar pengaruhnya dalam menarik netizen lain untuk ikut berinteraksi dan membaca berita di media online Detik.com.

Detik.com merupakan portal berita media online yang paling banyak diakses oleh masyarakat di Indonesia, hal ini terbukti berdasarkan data dari Alexa.com, bahwa kurang lebih dari 2 juta orang mengakses portal berita media online Detik.com. Selain itu, page view (jumlah halaman yang diakses) Detik.com mencapai 4 juta perharinya dan sekarang Detik.com menempati posisi pertama untuk situs portal berita di Indonesia (Alexa.com, 2018).

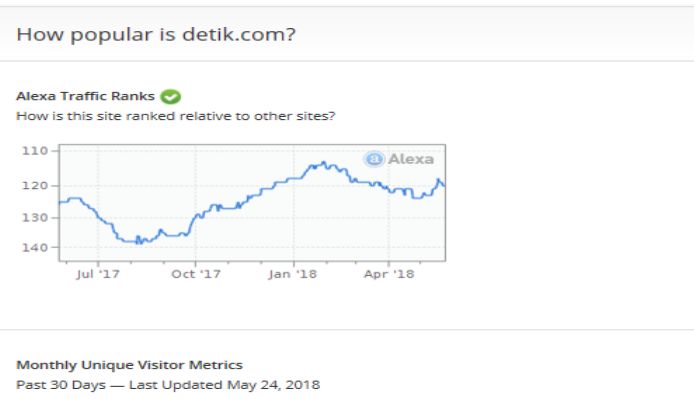

Sumber : Alexa.com

Melihat fenomena tersebut maka dapat dilihat adanya ketertarikan yang besar terhadap media online dalam mencari berita. Penulis tertarik untuk melihat lebih mendalam pengaruh headline berita dan komentar netizen pada kolom komentar terhadap minat membaca berita di media massa online detik.com.

\section{Tinjauan Pustaka}

Teori uses and gratifications (kegunaan dan kepuasan) pertama kali dikenalkan oleh Herbert Blumer dan Elihu Kartz pada tahun 1974 dalam bukunya The Uses On Mass Communication : Current Perspective On Gratification Research. Teori ini mengatakan bahwa pengguna media memainkan peran aktif untuk memilih dan 


\section{Acta Diurna Vol 15 No 1 Tahun 2019}

menggunakan media tersebut, dengan kata lain pengguna media adalah pihak yang aktif dalam proses komunikasi.

Pengguna media berusaha untuk mencari sumber media yang paling baik di dalam usaha untuk memenuhi kebutuhannya. Artinya teori uses and gratifications mengasumsikan bahwa pengguna mempunyai pilihan alternatif untuk memuaskan kebutuhan. (Nurudin, 2014 : 191-192).

Katz, Blumber \& Gurevitch menjelaskan mengenai asumsi dasar dari teori uses and gratifications, yaitu :

1. Khalayak dianggap aktif, artinya khalayak sebagai bagian penting dari penggunaan media massa diasumsikan mempunyai tujuan.

2. Dalam proses komunikasi massa, inisiatif untuk mengaitkan pemuasan kebutuhan dengan pemilihan media terletak pada khalayak.

3. Media massa harus bersaing dengan sumber-sumber lain untuk memuaskan kebutuhannya. Kebutuhan yang dipenuhi media massa lebih luas. Bagaimana kebutuhan ini terpenuhi melalui konsumsi media amat bergantung pada perilaku khalayak yang bersangkutan.

4. Tujuan pemilih media massa disimpulkan dari data yang diberikan anggota khalayak. Artinya, orang diangap cukup mengerti untuk melaporkan kepentingan dan motif pada situasi-situasi tertentu.

5. Penilaian tentang arti kultural dari media massa harus ditangguhkan sebelum diteliti lebih dahulu orientasi khalayak. (Elvinaro, $2014: 74)$

Pendekatan teori uses and gratifications ditujukan untuk menggambarkan proses penerimaan dalam komunikasi massa dan menjelaskan penggunaan media oleh individu atau agregasi individu. (Daryanto, $2016: 148$ ) 


\section{Acta Diurna Vol 15 No 1 Tahun 2019}

Teori uses and gratifications ini bertujuan untuk menjelaskan informasi yang ada di dalam media terutama media massa. Dalam teori ini audiens tidak lagi dipandang sebagai orang pasif yang hanya menerima informasi yang disampaikan oleh media, tapi audiens berlaku aktif dan selektif dan juga kritis terhadap semua informasi yang disampaikan oleh media.

Peneliti menggunakan teori ini karena terpaan media berbicara tentang frekuensi, durasi dan atensi dalam menggunakan media online. Disini khalayak adalah orang yang aktif dalam mengakses media online guna memenuhi kepuasan untuk memenuhi kebutuhan dalam mencari informasi.

\section{Teori Stimulus Organism Respons}

Teori ini memiliki tiga elemen yakni pesan (stimulus), penerima (organism), dan efek (response). Stimulus adalah sumber rangsangan, organism adalah penerima rangsangan, dan respon adalah umpan balik yang dihasilkan.

Teori S-O-R sebagai singkatan dari Stimulus-Organism-Response ini semula berasal dari psikologi. Kalau kemudian juga menjadi teori komunikasi, tidaklah mengherankan karena objek material dari psikologi dan komunikasi adalah sama, yaitu manusia yang jiwanya meliputi komponen-komponen : sikap, opini, perilaku, kognisi, afeksi, dan konasi. (Effendi, 2003:254).

Dalam kaitan dengan teori S-O-R ketika sebuah media online membuat headline berita, maka akan menstimulus kepada para pembaca yang akhirnya akan memiliki respon untuk melakukan klik pada headline berita tersebut, kemudian jika kembali menerima stimulus pada saat membaca berita dan melihat kolom komentar, maka bisa membuat respon juga untuk berkomentar pada kolom komentar.

\section{Media Online}




\section{Acta Diurna Vol 15 No 1 Tahun 2019}

Asep Syamsul M. Romli dalam buku jurnalistik Online : Panduan Mengelola Media Online (Nuansa, Bandung, 2012) mengartikan media online sebagai berikut : Media online (online media) adalah media massa yang tersaji secara online di situs web (website) internet. Masih menurut Romli dalam buku tersebut, media online adalah media massa "generasi ketiga" setelah media cetak (printed media) -koran, tabloid, majalah, buku-dan media elektronik (electronic media) -radio, televisi, dan film/video. Media Online merupakan produk jurnalistik online. Jurnalistik online -disebut juga cyber journalisme- didefinisikan wikipedia sebagai "pelaporan fakta atauperistiwa yang diproduksi dan didistribusikan melalui internet". Secara teknis atau "fisik", media online adalah media berbasis telekomunikasi dan multimedia (komputer dan internet)

\section{Headline Berita}

Headline sering juga dilengkapi dengan anak headline. Bagian ini berguna untuk menolong pembaca agar segera mengetahui peristiwa yang akan diberikan dan menonjolkan satu berita dengan dukungan teknik grafika.

Dalam Kamus Besar Bahasa Indonesia, headline adalah nama yang dipakai untuk buku atau bab dalam buku yg dapat menyiratkan secara pendek isi atau maksud buku atau bab itu. Headline adalah perincian atau penjabaran dari topik. Headline lebih spesifik dan sering telah menyiratkan permasalahan atau variabel yang akan dibahas.

Sedangkan berita, dalam Kamus Besar Bahasa Indonesia adalah cerita atau keterangan mengenai kejadian atau peristiwa yg hangat; kabar: Kata "berita" sendiri berasal dari kata sangsekerta, vrit (ada atau terjadi) atau vritta (kejadian atau peristiwa).Berita dalam bahasa Inggris disebut News. Dalam The Oxford Paperback Dictionary terbitan Oxford University Press (1979), news diartikan sebagai “informasi tentang peristiwa terbaru". 


\section{Acta Diurna Vol 15 No 1 Tahun 2019}

Dari penjabaran di atas, dapat disimpulkan pengertian Headline berita adalah frasa atau kalimat yang menggambarkan keseluruhan isi berita.

\section{Komentar}

Salah satu bentuk nyata dari karakteristik dari new media dan media online yaitu adanya interaksi antar pengguna. Interaksi antar pengguna bisa terjadi pada kolom komentar, dimana kolom komentar adalah wadah yang disediakan pada suatu media online untuk berinteraksinya pengguna setelah membaca berita yang sudah dimuat.

Dalam sebuah media online, komentar netizen berupa ulasan atau tanggapan dari artikel yang dibuat pada suatu media online. Ada berbagai macam komentar netizen pada kolom komentar, ada yang pro dengan isi artikel, namun ada juga yang kontra dengan isi artikel tersebut, tergantung dari sudut pandang yang digunakan oleh netizen itu sendiri.

Komentar netizen pada kolom komentar bisa digunakan sebagai acuan untuk membuat konten, jika masih banyak netizen yang aktif berkomentar dalam artikel tersebut maka akan dibuat kembali konten yang serupa.

Riset Engaging News Project menunjukkan bahwa kolom komentar tidak diabaikan begitu saja oleh para jurnalis. Lebih dari itu, para jurnalis terlibat dan berinteraksi dengan para komentator khususnya terkait artikel yang mereka tulis. Selain itu, dari temuan yang ada interaksi antara jurnalis dan pembaca akan meminimalisir komentar-komentar bernada kasar yang kerap muncul karena kesalahpahaman membaca berita.

\section{Metodologi}

Berdasarkan pada permasalahan yang diteliti, metode yang digunakan adalah metode kuantitatif. Menurut Sugiyono dalam buku Metode Penelitian Kuantitatif, 


\section{Acta Diurna Vol 15 No 1 Tahun 2019}

Kualitatif, dan R\&D (2015:8) kuantitatif merupakan sebuah metode penelitian yang menggunakan data penelitian berupa angka-angka dan analisis dengan menggunakan statistik, dengan tujuan menguji hipotesis yang telah diterapkan. Penelitian kuantitatif pada umumnya dilakukan pada sampel yang diambil secara random, sehingga kesimpulan hasil penelitian dapat digeneralisasikan pada populasi dimana sampel tersebut diambil.

Penelitian ini menggunakan metodologi kuantitatif untuk meneliti mengenai pengaruh headline berita dan komentar netizen pada kolom komentar terhadap minat membaca berita di media online Detik.com.

Metode penelitian yang digunakan dalam penelitian ini adalah survey. Survey adalah pengamatan atau penyelidikan secara kritis untuk mendapatkan keterangan yang tepat terhadap suatu persoalan dan objek tertentu, di daerah kelompok komunitas atau lokasi tertentu yang ditelaah.

\section{Subjek Penelitian}

Subyek penelitian dalam penelitian ini adalah pembaca berita atau netizen dari media online Detik.com.

\section{Objek Penelitian}

Objek penelitian merupakan suatu permasalahan yang dijadikan topik penulisan dalam rangka menyusun laporan.

\section{Sumber Data}

Data primer berasal dari pembaca berita atau netizen media online Detik.com.

\section{Teknik Pengumpulan Data}

\section{Kuesioner}




\section{Acta Diurna Vol 15 No 1 Tahun 2019}

Kuesioner dibagikan kepada para pembaca berita atau netizen media online Detik.com, yang telah ditetapkan untuk dijadikan sampel pada penelitian ini. Untuk memberikan kadar penilaian data jawaban responden dipergunakan skala Likert.

\section{Studi Kepustakaan}

Studi kepustakaan ini diperoleh dari buku-buku yang ada hubungannya dengan komunikasi serta bahan-bahan lain untuk memperoleh teori maupun data yang berhubungan dengan masalah yang diteliti.

\section{Populasi}

Populasi dalam penelitian ini, melibatkan para netizen media online Detik.com.

\section{Sampel}

Sampel pada penelitian penulis yaitu sebanyak 96 responden.

\section{Metode Pengujian Instrumen}

\section{Uji Validitas}

Uji validitas digunakan untuk mengetahui kelayakan butir-butir dalam suatu daftar pertanyaan dalam mendefinisikan suatu variabel.

\section{Uji Reliabilitas}

Reliabilitas penelitian merupakan kondisi penting bagi validitas.

\section{Teknis Analisis Data}

Kegiatan dalam analisis data adalah mengelompokan data berdasarkan variabel dan jenis responden, mentabulasi data berdasarkan variabel dari seluruh responden, menyajikan data tiap variabel yang diteliti, melakukan perhitungan untuk menjawab rumusan masalah dan melakukan perhitungan untuk menguji hipotesis yang telah diajukan.

\section{Hasil Penelitian}




\section{Acta Diurna Vol 15 No 1 Tahun 2019}

\section{Deskripsi Responden}

Responden terdiri atas 50 responden perempuan dan 46 responden laki-laki. Responden dari berbagai usia : kurang dari 20 tahun 1 responden (1\%), responden yang berusia 20-30 tahun 88 responden (92\%), responden yang berusia 31-40 tahun 4 responden (4\%), dan responden yang berusia lebih dari 40 tahun 3 responden (3\%).

Responden yang berpendidikan terakhir SMA/Sederajat 25 responden (26\%), responden yang berpendidikan terakhir D III 33 responden (34\%), responden yang berpendidikan terakhir S1k 35 responden (37\%), dan responden yang berpendidikan terakhir S2 3 responden (3\%).

Responden yang bekerja sebagai pegawai swasta, yaitu sebanyak 56 responden (58\%), responden yang bekerja sebagai pegawai negeri sipil 2 responden (2\%), responden yang bekerja sebagai wiraswasta 15 responden (16\%), dan responden yang bekerja lainnya 23 responden $(24 \%)$.

\section{Pengujian Instrumen Penelitian}

\section{Uji Validitas}

Berikut hasil perhitungan uji validitas untuk Variabel X1 (Headline Berita) dapat dilihat pada tabel berikut ini :

\begin{tabular}{|c|c|c|c|}
\hline \multicolumn{4}{|c|}{ X $_{1}$ (Headline Berita) } \\
\hline Item & Rhitung & Rtabel & Ket \\
\hline P1 & 0.601 & 0.237 & Valid \\
\hline P2 & 0.523 & 0.237 & Valid \\
\hline P3 & 0.401 & 0.237 & Valid \\
\hline P4 & 0.659 & 0.237 & Valid \\
\hline P5 & 0.763 & 0.237 & Valid \\
\hline P6 & 0.698 & 0.237 & Valid \\
\hline P7 & 0.719 & 0.237 & Valid \\
\hline
\end{tabular}




\begin{tabular}{|c|c|c|c|}
\hline P8 & 0.755 & 0.237 & Valid \\
\hline P9 & 0.592 & 0.237 & Valid \\
\hline P10 & 0.816 & 0.237 & Valid \\
\hline
\end{tabular}

Berikut hasil perhitungan uji validitas untuk Variabel X2 (Komentar Netizen) dapat dilihat pada tabel berikut ini

\begin{tabular}{|c|c|c|c|}
\hline \multicolumn{4}{|c|}{ X2 (Komentar Netizen) } \\
\hline Item & Rhitung & Rtabel & Ket \\
\hline P1 & 0.709 & 0.237 & Valid \\
\hline P2 & 0.862 & 0.237 & Valid \\
\hline P3 & 0.680 & 0.237 & Valid \\
\hline P4 & 0.778 & 0.237 & Valid \\
\hline P5 & 0.629 & 0.237 & Valid \\
\hline P6 & 0.642 & 0.237 & Valid \\
\hline
\end{tabular}

Berikut hasil perhitungan uji validitas untuk Variabel Y (Minat Membaca Berita) dapat dilihat pada tabel berikut ini :

\begin{tabular}{|c|c|c|c|}
\hline \multicolumn{4}{|c|}{ Y (Minat Membaca Berita) } \\
\hline Item & Rhitung & Rtabel & Ket \\
\hline P1 & 0.753 & 0.237 & Valid \\
\hline P2 & 0.779 & 0.237 & Valid \\
\hline P3 & 0.488 & 0.237 & Valid \\
\hline P4 & 0.509 & 0.237 & Valid \\
\hline P5 & 0.567 & 0.237 & Valid \\
\hline P6 & 0.756 & 0.237 & Valid \\
\hline P7 & 0.471 & 0.237 & Valid \\
\hline P8 & 0.692 & 0.237 & Valid \\
\hline P9 & 0.669 & 0.237 & Valid \\
\hline P10 & 0.611 & 0.237 & Valid \\
\hline P11 & 0.727 & 0.237 & Valid \\
\hline P12 & 0.572 & 0.237 & Valid \\
\hline
\end{tabular}




\section{Acta Diurna Vol 15 No 1 Tahun 2019}

\begin{tabular}{|l|l|l|l|}
\hline P13 & 0.606 & 0.237 & Valid \\
\hline
\end{tabular}

\section{Uji Reliabilitas}

Berikut hasil perhitungan uji rebilitas dari setiap variabel dalam penelitian ini.

\begin{tabular}{|l|l|l|c|}
\hline \multicolumn{1}{|c|}{ Variabel } & Kriteria & $\begin{array}{c}\text { Nilai Alpha } \\
\text { Cronbach }\end{array}$ & Ket \\
\hline $\begin{array}{l}\mathrm{X}_{1} \\
\text { (Headline } \\
\text { Berita) }\end{array}$ & $>0.60$ & 0.847 & Reliable \\
\hline $\begin{array}{l}\mathrm{X}_{2} \\
\text { (Komentar } \\
\text { Netizen) }\end{array}$ & $>0.60$ & 0.806 & Reliable \\
\hline $\begin{array}{l}\text { Y (Minat } \\
\text { Membaca } \\
\text { Berita) }\end{array}$ & $>0.60$ & 0.873 & Reliable \\
\hline
\end{tabular}

\section{Analisis Regresi Linier Berganda}

Ringkasan hasil pengolahan data dengan menggunakan program SPSS tersebut adalah sebagai berikut :

\begin{tabular}{|ll|c|c|}
\hline \multicolumn{4}{|c|}{ Coefficients $^{\mathrm{s}}$} \\
\multicolumn{2}{|c|}{} & \multicolumn{2}{c|}{ Unstandardized Coefficients } \\
\cline { 3 - 4 } Model & & $\mathrm{B}$ & Std. Error \\
\hline 1 & (Constant) & 4.377 & 3.733 \\
& Judul Berita & .580 & .128 \\
& Komentar Netizen & .818 & .158 \\
\hline
\end{tabular}

a. Dependent Variable: Minat Membaca Berita

Dari hasil tersebut apabila ditulis dalam bentuk standardized dari persamaan regresinya adalah sebagai berikut :

$$
\widehat{Y}=4,377+0,580 X_{1}+0,818 X_{2}
$$

Koefisien regresi untuk variabel X1 sebesar 0,580 dan variabel X2 sebesar 0,818. Koefisien regresi X1 bernilai positif artinya pada saat Headline Berita menarik maka Minat untuk membaca berita juga akan mengalami peningkatan. Begitu pula pada saat headline berita tidak menarik maka minat membaca berita juga turun. Koefisien regresi X2 bernilai positif memiliki arti yang sama dengan koefisien regresi X1. Pada 


\section{Acta Diurna Vol 15 No 1 Tahun 2019}

saat komentar netizen meningkat maka minat membaca berita juga akan mengalami peningkatan. Begitu pula pada saat komentar netizen sedikit maka minat membaca berita juga menurun.

\section{Hasil Uji Asumsi}

Berikut adalah hasil uji multikolinearitas berdasarkan nilai Variance Inflation Factor (VIF), dan nilai tolerance :

Coefficients $^{\mathrm{a}}$

\begin{tabular}{|cc|c|c|}
\hline \multirow{2}{*}{} & \multirow{2}{*}{ Model } & \multicolumn{2}{|c|}{ Collinearity Statistics } \\
\cline { 3 - 4 } & Tolerance & VIF \\
\hline 1 & (Constant) & & \\
& Judul Berita & .607 & 1.648 \\
& Komentar Netizen & .607 & 1.648 \\
\hline
\end{tabular}

a. Dependent Variable: Minat Membaca Berita

Nilai VIF untuk variabel Headline Berita dan Komentar Netizen sama-sama 1,648, sedangkan Tolerance-nya 0,607. Karena nilai VIF dari kedua variabel tidak ada yang lebih besar dari 10 atau 5 maka dapat dikatakan tidak terjadi multikolinieritas pada kedua variabel bebas tersebut.

Berdasarkan syarat asumsi klasik regresi linier berganda, maka model regresi linier yang baik adalah yang terbebas dari adanya multikolinieritas. Dengan demikian, model di atas telah terbebas dari adanya multikolinieritas.

Hasil uji autokorelasi, dapat dilihat pada tabel Model Summary ${ }^{\mathrm{b}}$

\begin{tabular}{|c|c|c|c|c|c|}
\hline Model & $\mathrm{R}$ & R Square & $\begin{array}{c}\text { Adjusted R } \\
\text { Square }\end{array}$ & $\begin{array}{c}\text { Std. Error of the } \\
\text { Estimate }\end{array}$ & Durbin-Watson \\
\hline 1 & $.759^{\circ}$ & .576 & .567 & 6.226 & 2.026 \\
\hline
\end{tabular}
a. Predictors: (Constant), Komentar Netizen, Judul Berita
b. Dependent Variable: Minat Membaca Berita

Nilai DW hitung sebesar 2,026 lebih besar dari 1,710 dan lebih kecil dari 2,290 yang artinya berada pada daerah tidak ada autokorelasi. Sehingga dapat disimpulkan bahwa dalam model regresi linier tidak terjadi autokorelasi. 


\section{Acta Diurna Vol 15 No 1 Tahun 2019}

Berikut adalah hasil uji normalitas menggunakan grafis Normal P-Plot dari standardized residual cumulative probability :

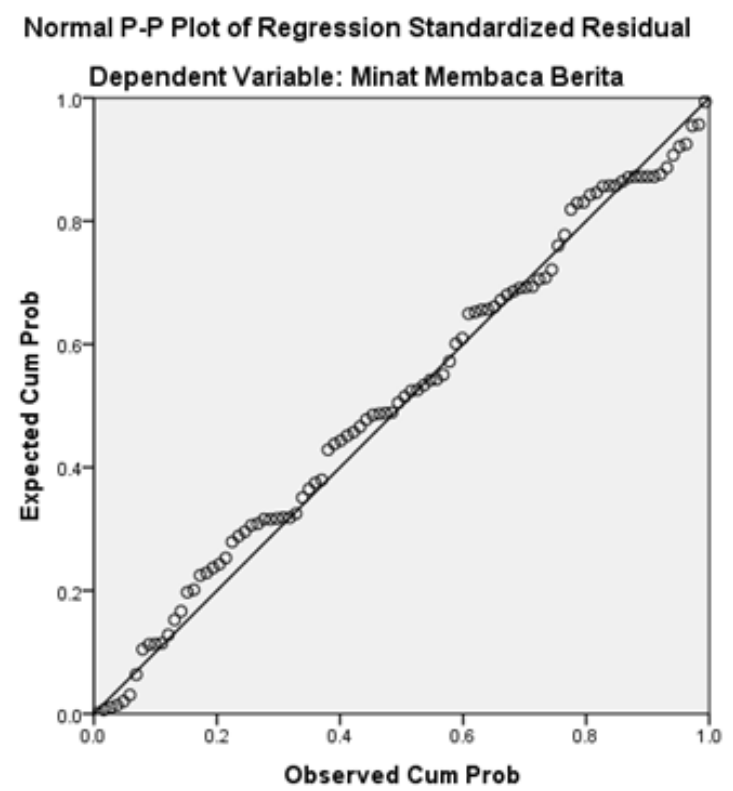

Jika dilihat berdasarkan di atas, maka dapat diketahui sebaran titik-titik dari gambar Normal P-P Plot di atas relatif mendekati garis lurus, sehingga dapat disimpulkan bahwa (data) residual terdistribusi normal. Sehingga dapat disimpulkan bahwa data dalam model regresi terdistribusi normal.

Hasil uji heteroskedastisitas dapat dilihat pada gambar Scatterplot, seperti pada gambar di bawah ini:

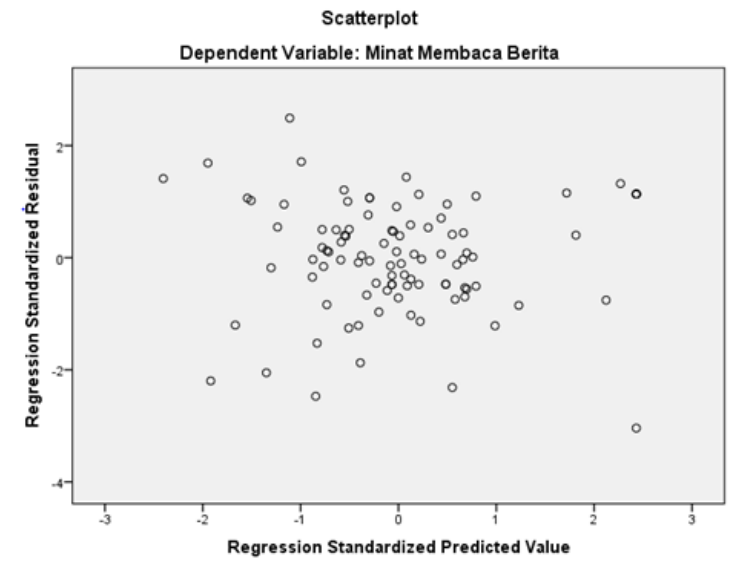

Dari gambar di atas terlihat bahwa sebaran titik tidak membentuk suatu pola/alur tertentu, sehingga dapat disimpulkan tidak terjadi heteroskedastisitas atau 


\section{Acta Diurna Vol 15 No 1 Tahun 2019}

dengan kata lain terjadi homoskedastisitas. Asumsi klasik tentang heteroskedastisitas dalam model ini terpenuhi, yaitu terbebas dari heteroskedastisitas.

Dengan demikian, asumsi-asumsi klasik seperti multikolinearitas, autokorelasi, normalitas dan heteroskedastisitas dalam model regresi dapat dipenuhi dari model ini.

\section{Uji Koefisien Determinasi (R square)}

Koefisien determinasi ( $\mathrm{R}$ square) menjelaskan variasi pengaruh variabelvariabel bebas terhadap variabel terikatnya. Atau dapat pula dikatakan sebagai proporsi pengaruh seluruh variable bebas terhadap variabel terikat. Berikut adalah hasil dari analisis koefisien determinasi :

\begin{tabular}{|c|c|c|c|}
\hline Model & $\mathrm{R}$ & R Square & Adjusted R Square \\
\hline 1 & $.759^{\circ}$ & .576 & .567 \\
\hline
\end{tabular}
a. Predictors: (Constant), Komentar Netizen, Judul Berita
b. Dependent Variable: Minat Membaca Berita

Jika dilihat dari nilai adjusted $\mathrm{R}$ square yang besarnya 0,567 menunjukkan bahwa proporsi pengaruh variabel Headline Berita dan Komentar Netizen terhadap variabel Minat Membaca Berita sebesar 56,7\%. Artinya, Headline Berita dan Komentar Netizen memiliki proporsi pengaruh terhadap Minat Membaca Berita. Jadi sebesar $56,7 \%$ sedangkan sisanya 43,3\% (100\% - 56,7\%) dipengaruhi oleh variabel lain yang tidak ada didalam model regresi linier.

\section{Uji Koefisien Regresi Secara Bersama-sama (Uji F)}

Hasil uji F dapat dilihat pada tabel ANOVAa di bawah ini. Nilai prob. F hitung terlihat pada kolom terakhir (sig.)

\begin{tabular}{|c|c|c|c|c|c|c|}
\hline \multicolumn{7}{|c|}{$A^{\prime} O{ }^{D}{ }^{\circ}$} \\
\hline & Model & Sum of Squares & df & Mean Square & $\mathrm{F}$ & Sig. \\
\hline \multirow[t]{3}{*}{1} & Regression & 4898.374 & 2 & 2449.187 & 63.174 & $.000^{\circ}$ \\
\hline & Residual & 3605.532 & 93 & 38.769 & & \\
\hline & Total & 8503.906 & 95 & & & \\
\hline
\end{tabular}




\section{Acta Diurna Vol 15 No 1 Tahun 2019}

Berdasarkan table diatas dapat dilihat bahwa nilai Sig. yaitu 0,00 lebih kecil dari 0,05. Dengan demikian maka hipotesis yang diterima yaitu secara simultan atau secara keseluruhan Headline berita dan komentar netizen memberikan pengaruh secara signifikan terhadap minat membaca berita di media online Detik.com.

\section{Uji Koefisien Regresi Secara Parsial}

Hasil pengujian dapat dilihat pada tabel Coefficientsa seperti pada tabel di bawah ini:

Coefficients $^{\mathrm{s}}$
\begin{tabular}{|cc|c|c|}
\hline \multicolumn{1}{|l|}{} & $\mathrm{t}$ & Sig. \\
\hline $1 \quad$ & (Constant) & 1.173 & .244 \\
& Judul Berita & 4.525 & .000 \\
& Komentar Netizen & 5.176 & .000 \\
\hline
\end{tabular}

a. Dependent Variable: Minat Membaca Berita

Nilai prob. t hitung dari variabel bebas Headline Berita sebesar 0,000 yang lebih kecil dari 0,05 sehingga variabel bebas Headline Berita berpengaruh signifikan terhadap variabel terikat Minat Membaca Berita pada alpha 5\% atau dengan kata lain, Headline Berita berpengaruh signifikan terhadap Minat Membaca Berita pada taraf keyakinan $95 \%$.

Sama halnya dengan pengaruh variabel bebas Komentar Netizen terhadap variabel terikat Minat Membaca Berita, karena nilai prob. $t$ hitung $(0,000)$ yang lebih kecil dari 0,05 sehingga dapat dikatakan bahwa variabel bebas Komentar Netizen berpengaruh signifikan terhadap variabel terikat Minat Membaca Berita pada alpha 5\% atau dengan kata lain, Komentar Netizen berpengaruh signifikan terhadap Minat Membaca Berita pada taraf keyakinan 95\%.

\section{DISKUSI}




\section{Acta Diurna Vol 15 No 1 Tahun 2019}

Berdasarkan hasil perhitungan pengujian yang dilakukan dalam penelitian ini adalah untuk mengetahui bagaimana pengaruh headline berita dan komentar netizen terhadap minat membaca berita di media online Detik.com. Dari hasil pengujian yang telah dilakukan peneliti, dapat dilihat bahwa terdapat pengaruh secara simultan atau keseluruhan antara headline berita dan komentar netizen dengan minat membaca berita. Hal ini dapat dilihat dari hasil perhitungan hipotesis, yaitu Ho ditolak dan Ha diterima. Hipotesis dalam penelitian ini dapat terbukti dengan pengujian F-test dengan kata lain; "Headline berita dan komentar netizen memberikan pengaruh positif dan signifikan terhadap minat membaca berita di media online Detik.com”. Pernyataan ini juga dikuatkan dengan pernyataan bahwa variabel headline berita dan komentar netizen mempunyai konstribusi yaitu sebesar 56,7\% dalam menarik minat membaca berita, sedangkan sisanya sebesar $43,3 \%$ terbentuk akibat dari pengaruh beberapa faktor lainnya diluar dari penelitian ini.

Hasil dari penelitian didukung oleh penelitian terdahulu yang dilakukan Raisha Dwi Mayangsari sebanyak 50,8\% menunjukkan bahwa media sosial mempengaruhi pengikut Twitter membaca untuk membaca berita online. Perbedaan terletak pada medianya.

Ulfah Nur Aini Ningrum menjelaskan hal yang sama bahwa tautan headline berita memberikan pengaruh untuk membaca berita 10,40\%. Dewi Ambarwati Arifin menguatkan penelitian ini dengan hasil penelitian bahwa tautan headline berita memberikan pengaruh untuk membaca berita sebesar 35,80\%. Artinya memang headline berita memberikan pengaruh kepada pembacanya untuk membaca berita itu sendiri, sehingga dalam membuat headline berita sebuat artikel harus menarik agar dapat menarik minat pembaca. 


\section{Acta Diurna Vol 15 No 1 Tahun 2019}

Dikaitkan dengan asumsi teori yang digunakan dalam penelitian ini yaitu Uses And Grattifications Theory, yang berasumsi bahwa inisiatif untuk mendapatkan kepuasan media ditentukan audiensi dan asumsi bahwa audiens sadar sepenuhnya terhadap ketertarikan, motif dalam penggunaan media, maka dapat dikatakan ketika headline sebuah berita ditulis dengan sangat menarik maka akan meningkatkan minat untuk membaca berita, namun jika headline berita dibuat dengan biasa saja dan tidak mengundang rasa penasaran pembaca untuk membca, maka minat untuk membaca berita itu sendiri pun turun.

Begitu juga dengan komentar netizen, apabila netizen banyak berkomentar dan komentarnya lebih banyak mendukung berita maka pembaca pun akan terbawa untuk membaca berita. Hal tersebut sesuai dengan teori uses and gratification bahwa pengguna media dalam hal ini pembaca memiliki kebutuhan tertentu yang mendorong terjadinya penggunaan media (uses) untuk memperoleh kepuasan (gratifications) berupa meningkatnya minat membaca berita setelah melihat headline berita dan juga komentarkomentar netizen.

Jika dikaitkan dengan teori S-O-R yang melihat dari sifat ketertarikan pengguna untuk membaca suatu berita, apabila penulisan headline berita menarik maka akan menstimulus kepada para pembaca yang akhirnya akan memiliki respon untuk melakukan klik pada headline berita tersebut, kemudian jika kembali menerima stimulus pada saat membaca berita dan melihat kolom komentar, maka bisa membuat respon juga untuk berkomentar pada kolom komentar.

Sesuai dengan teori uses and gratification maka dapat dijelaskan bahwa pengguna memiliki kebutuhan tertentu yang mendorong terjadinya penggunaan media (uses) untuk memperoleh kepuasan (gratifications) berupa meningkatnya minat membaca berita dan juga teori S-O-R yang melihat sifat ketertarikan pengguna untuk 


\section{Acta Diurna Vol 15 No 1 Tahun 2019}

membaca suatu berita. Dan hasil dari penelitian ini menjelaskan bahwa variabel headline berita dan komentar netizen mempunyai konstribusi yaitu sebesar 56,7\% dalam menarik minat membaca berita, sedangkan sisanya sebesar 43,3\% terbentuk akibat dari pengaruh beberapa faktor lainnya diluar dari penelitian ini. Ada kemungkinan faktor lain yang terjadi yaitu pembaca tidak terlalu memperhatikan headline dari sebuah berita, namun berdasarkan rasa ingin tahu pada suatu kasus berita sehingga membaca semua berita tentang kasus tersebut tanpa terlalu memperhatikan sebuah headline berita. Demikian pula dengan komentar netizen, kemungkinan ada pembaca berita yang tidak pernah membaca atau memperdulikan komentar-komentar netizen di kolom komentar, sehingga pembaca tersebut hanya membaca beritanya saja.

\section{KESIMPULAN}

Kesimpulan yang didapat adalah sebagai berikut :

1. Terdapat pengaruh antara variabel headline berita dengan minat membaca berita di media online Detik.com. Hubungan antara kedua variabel juga memiliki arah hubungan yang positif, artinya apabila sebuah headline berita semakin menarik, komunikatif, informatif dan sesuai dengan isi berita maka minat untuk membaca berita juga akan mengalami peningkatan.

2. Terdapat pengaruh antara variabel komentar netizen dengan minat membaca berita di media online Detik.com. Hubungan antara kedua variabel juga memiliki arah hubungan yang positif, dimana apabila netizen suka membaca komentar dan berinteraksi dengan netizen lain maka minat untuk membaca berita lain yang masih berkaitan dengan topik tersebut akan mengalami peningkatan.

3. Secara simultan atau secara keseluruhan antara variabel headline berita dan komentar netizen, keduanya memberikan pengaruh yang signifikan terhadap minat membaca 


\section{Acta Diurna Vol 15 No 1 Tahun 2019}

berita di media online Detik.com. Sesuai dengan teori yang digunakan peneliti yaitu teori uses and gratification menjelaskan bahwa pengguna memiliki kebutuhan tertentu yang mendorong terjadinya penggunaan media (uses) untuk memperoleh kepuasan (gratifications) berupa meningkatnya minat baca mahasiswa ketika melihat headline berita dan komentar netizen di media online Detik.com. Jika dikaitkan dengan teori S-O-R yang melihat dari sifat ketertarikan pengguna untuk membaca suatu berita, apabila penulisan headline berita menarik maka akan menstimulus kepada para pembaca yang akhirnya akan memiliki respon untuk melakukan klik pada headline berita tersebut, kemudian jika kembali menerima stimulus pada saat membaca berita dan melihat kolom komentar, maka bisa membuat respon juga untuk berkomentar pada kolom komentar.

\section{Saran}

Adapun saran dari penulis adalah sebagai berikut :

1. Disarankan untuk penelitian sejenis selanjutnya melakukannya dengan lebih mendalam. Hal ini dikarenakan pada penelitian ini masih adanya nilai netral terutama pada variabel pengaruh komentar netizen pada kolom komentar.

2. Disarankan untuk pihak media online untuk memperhatikan lagi headline berita yang dibuat pada suatu berita dikarenakan headline berita adalah piranti utama untuk menarik minat membaca berita atau melakukan klik pada headline tersebut tentunya harus tetap mematuhi kaidah-kaidah jurnalistik

\section{DAFTAR PUSTAKA}

Ardianto, Elvinaro., Komala, Lukiati., dan Siti Karlinah. 2014. Komunikasi Massa Suatu Pengantar. Bandung : Simbiosa Rekatama Media.

Arikunto, Suharsimi. 2010. Manajemen Penelitian. Jakarta : Rineka Cipta. 


\section{Acta Diurna Vol 15 No 1 Tahun 2019}

Djaali. 2008. Psikologi Pendidikan. Jakarta : PT Bumi Aksara.

Djuraid, Husnun . 2009. Panduan Menulis Berita. Malang: UMM Press

Effendy, Onong Uchyana. 2003. Ilmu Komunikasi Teori dan Praktek. Bandung: Remaja Rosdakarya.

Ghozali, Imam. 2005. Aplikasi Analisis Multivariate Dengan Program SPSS Edisi Kedua. Semarang : Badan Penerbit Universitas Diponegoro.

Ghozali, Imam. 2011. Aplikasi Analisis Multivariate Dengan Program SPSS Edisi Kelima. Semarang : Badan Penerbit Universitas Diponegoro.

Kusumaningrat, Hikmat \& Purnama Kusumaningrat. 2006. Jurnalistik: Teori dan Praktek. Bandung. PT Remaja RosdaKarya.

Kriyantono, Rachmat. 2012. Teknik Praktis Riset Komunikasi. Jakarta : Kencana Prenada.

M. Romli, Asep Syamsul. 2000. Jurnalistik Praktis. Bandung: Remaja Rosda Karya.

Mcquail, Dennis. 2011. Teori Komunikasi Massa McQuail. Jakarta : Salemba Humanika.

Nurudin. 2015. Pengantar Komunikasi Massa. Jakarta : PT Raja Grafindo Persada.

Rohim, Syaiful. 2009. Teori Komunikasi Perspektif Ragam \& Aplikasi. Jakarta : Rineka Cipta.

Ruslan, Rosady. 2010. Metode Penelitian Public Relations Dan Komunikasi. Jakarta : PT Raja Grafindo Persada.

Semi, M. Atar. 1995. Teknik Penulisan Berita, Features, dan Artikel. Bandung: Angkasa.

Singarimbun, Masri., dan Sofian Effendy. 2011. Metode Penelitian Survai. Jakarta : Pustaka LP3ES

Sugiyono. 2015. Metode Penelitian Kuantitatif Kualitatif Dan R\&D. Bandung : Alfabeta

Suhandang. 2010. Pengantar Jurnalistik. Bandung : Nuansa.

Wiryanto. 2004. Pengantar Ilmu Komunikasi. Jakarta : Grasindo 